\title{
Johannesburg's "model white housing scheme" in the civic social imaginary: The genesis of a white Afrikaner welfarist node, 1933-1937
}

\section{Irma du Plessis*}

\begin{abstract}
Conceptualised in 1933, the Jan Hofmeyr Improvement Scheme was Johannesburg (and South Africa's) first subsidised municipal housing development for the white poor. Being a slum clearance intervention, its design was informed by the modernist imaginary of rational city planning and the social reformist aspirations of a "garden city"-style working class housing in metropolitan cities. Linked to Susan Parnell's seminal work on the crucial connection between slum clearance, council housing provision and racial segregation in Johannesburg, this is a micro-level analysis of the origins and completion of the Jan Hofmeyr scheme and the civic social imaginaries that shaped it. Focusing on the bureaucratic and political sections of the local state in relation to the Public Health Committee (PHC), it is argued that the city's medical officer of health (MOH), Dr H.L. Milne and Lionel Leveson, a city councillor, each brought a distinctive vision to the project, a vision that was also shaped by civil society organisations. The scheme became important as signifier of the city's racial modernity. Over the period of its construction, a shift took place in the PHC from bureaucratic concern with housing, linked to sanitation, hygiene, and racial segregation, to the incorporation of a welfarist function at local state level. Soon after completion of this project, the city abandoned sub-economic housing schemes. Sociopolitically, the site of the Jan Hofmeyr scheme led to the expansion and consolidation of a white Afrikaner welfare node to the west of the city, with a gradual but sure "whitening out" through forced removals of the broader area. Thus the foundations were laid for the later centrality of the area, and the Jan Hofmeyr township itself, to
\end{abstract}

* Irma du Plessis is a senior lecturer in the Department of Sociology at the University of Pretoria. Her email address is irma.duplessis@up.ac.za. She wishes to express the following acknowledgements. Thank you to Shireen Ally, Bridget Kenny and Michelle Williams for their supportive comments on an early draft; and to Malehoko Tshoaedi for ensuring that this work gets done. I also thank my erstwhile colleagues at WISER Deborah Posel, Jonathan Hyslop, Ivor Chipkin, Adila Deshmukh, Najibha Deshmukh, Pamila Gupta, Julia Hornberger, Achille Mbembe, Robert Muponde, Sarah Nuttall, Tom Odhiambo, and Michael Titlestad - for creating such a congenial atmosphere for intellectual work. My thanks also to the two anonymous reviewers for their intellectually generous and supportive comments. Finally, I am indebted to Susan Parnell, on whose solid foundations this work is built.

How to cite this article: I. du Plessis, "Johannesburg's 'model white housing scheme' in the civic social imaginary: The genesis of a white Afrikaner welfarist node, 1933-1937”, Historia, 61, 2, November 2016, pp 1-28. 
the Afrikaner Nationalist social imaginary. Efforts to uplift poor and working class white Afrikaners were concentrated here until well into the early 1990s.

Key words: poor whites; council housing; Johannesburg; Jan Hofmeyr scheme; racial modernity; social imaginaries; Octavia Hill; social upliftment; Public Health Committee.

\section{Opsomming}

Die Jan Hofmeyr-skema was Johannesburg (en Suid-Afrika) se eerste gesubsidieerde stadsraadbehuisingskema vir wit armes en is in 1933 gekonseptualiseer. Die projek het gespruit uit 'n poging om krotbuurte op te ruim en is deur die modernistiese verbeelding van rasionele stadsbeplanning en die sosiale hervormingsaspirasies van groengordel-voorstedelike behuisings-intervensies vir die werkersklas in metropolitaanse stede geïnspireer. Binne die raamwerk van Susan Parnell se invloedryke werk oor die verband tussen krotbuurt-opruiming, rasse-segregasie en stadsraadbehuising in Johannesburg, is hierdie 'n mikro-vlak ontleding van die ontstaan en voltooiing van Jan Hofmeyr en die siviele sosiale verbeelding wat hieraan beslag gegee het. Met 'n fokus op die onderskeid tussen burokratiese en politieke afdelings op plaaslike regeringvlak en in verband met die Openbare Gesondheidskomitee, word die argument aangebied dat die gesondheidsoffisier, $\mathrm{Dr}$ H.L. Milne en Lionel Leveson, 'n raadslid, elk 'n spesifieke visie vir die projek gehad het, maar dat burgerlike samelewingsorganisasies ook die projek beïnvloed het. Die skema was simbolies belangrik as vlagdraer van die stad se rasse-moderniteit. Gedurende die tydperk van die skema se konstruksie het 'n verskuiwing in die werksaamhede van OGK plaasgevind van 'n burokratiese fokus op sanitasie, higiëne en rasse-segregasie na die inkorporasie van 'n welsynsfunksie op plaaslike regeringsvlak. Kort na die voltooiing van die skema het die stad afgesien van subekonomiese behuisingsskemas. Sosio-polities het Jan Hofmeyr se ligging met verloop van tyd daartoe bygedra om 'n wit welsynsnode in die weste van die stad te vestig en die area daar rondom toenemend "uit te wit" deur gedwonge verskuiwings. Die fondasies was dus gelê vir die latere belangrikheid van die breër gebied, asook die Jan Hofmeyr-skema, in die Afrikaner-nasionalistiese verbeelding. Tot in die vroeë 1990s sou die gebied 'n konsentrasiepunt vir projekte om arm en werkersklas Afrikaners op te hef bly.

Sleutelwoorde: armblankes; munisipale behuisingskemas; Johannesburg; Jan Hofmeyr-skema; Octavia Hill; sosiale hervorming; rasse-moderniteit; sosiale verbeelding; Openbare Gesondheidskomitee

\section{Introduction}

In 1930, following the Great Depression and severe drought, and in response to what Parnell terms a political crisis produced by the increasing geographical spread of 
slums in urban areas and a rise in the number of whites in slum areas, ${ }^{1}$ the Hertzog government made a landmark decision to offer sub-economic loans through the Central Housing Board for white housing schemes. ${ }^{2}$ Its broader aim was to boost the ability of local authorities to clear white slum areas. ${ }^{3}$ Waiting for economic recovery, in 1933 Johannesburg embarked on its first sub-economic municipal housing scheme for whites, which, by a twist of fate, was the first in the country as well. ${ }^{4}$

A year before, the Carnegie Commission of Enquiry into the poor white problem, established in 1928, completed its report. A key recommendation was that the training of social workers should be prioritised in order to address problems associated with poor whiteism. ${ }^{5}$ This, then, was a call for the "social upliftment" of the white poor, a concept that could be imbued with various meanings, expressed in the language of economic, social and moral rehabilitation. In urban areas, the state was concerned about poor whites living in close proximity with other racial groups, fearing the potential for cross-racial intimacy and interracial class-based political support $^{6}$ in a colonial context where enfranchised whites were a minority. In Johannesburg, the issue of white poverty strained the political and social integration of the two white groups of South Africa - English and Afrikaans-speakers - with economic and political power largely in English hands and poverty concentrated among Afrikaners. ${ }^{7}$

While middle-class whites felt intense anxiety about so-called "poor whites", 8 there was concern among the stratum of educated Afrikaans professionals that services to the poor were largely being rendered through English civil society organisations and a sense that Afrikaners should be taking care of their "own

1. S.M. Parnell, "Council Housing Provision for Whites, 1920-1955", MA dissertation, University of the Witwatersrand, 1987, p 68.

2. For a summary on the nature and genesis of Johannesburg's housing crisis in the 1930s see S. Parnell, "Public Housing as a Device for White Residential Segregation in Johannesburg, 1934-1953”, Urban Geography, 9, 6 (1988), pp 584-602.

3. Parnell, “Council Housing Provision”, p 65.

4. Cape Town embarked on sub-economic housing schemes for whites earlier, but this was done through the vehicle of public housing utility companies.

5. I.R. Hare and W. Hoffmann, "Social Work Education at Wits, 1937-1987", School of Social Work, University of the Witwatersrand, Johannesburg, 1987, cited in E. Ross, "The History of the Department of Social Work at Wits, 1937-2007", Unpublished brochure, 2007.

6. K. Beavon, Johannesburg: The Making and Shaping of the City (UNISA Press, Pretoria, 2004), p 110.

7. E.L.P. Stals (ed.), Afrikaners in die Goudstad, Deel 2 (HAUM, Pretoria, 1986), cited in I. du Plessis, "Living in Jan Bom: Making and Imagining Lives after Apartheid in a Council Housing Scheme in Johannesburg", Current Sociology, 52, 5 (2004), p 882.

8. S. Klausen, "Poor Whiteism, White Maternal Mortality and the Promotion of Public Health in South Africa: The Department of Public Health's Endorsement of Contraceptive Services, 1930-1938", South African Historical Journal, 45, 1 (2001), p 56; Beavon, Johannesburg, p 110. 
people". ${ }^{9}$ Some of the popular and social-scientific discourses of the era on which many civil society organisations drew - originating from metropolitan countries and espoused at South African universities - fed into degeneracy and fecundity fears with respect to white lower and working class strata. These debates had a cultural and racial inflection, given that white Afrikaners had large families; ${ }^{10}$ there were also fears about racial miscegenation. Although eugenicist and biological determinist positions did feature locally, ${ }^{11}$ there were also more sociological explanations for the poor white phenomenon. Klausen argues that many participants in the birth control movement, for example, did not subscribe to biological determinist beliefs and argued that "poor whites were made, not born". ${ }^{12}$ In the context of the slums crisis, then, white housing provision and the politics of white fertility and maternalism therefore featured strongly in a broader state and civil society effort to consolidate white urban advancement in an industrial economy, embedded in a racial segregationist project. ${ }^{13}$

Johannesburg's decision to provide subsidised public housing for whites therefore did not emerge primarily from city health and philanthropic concerns. Parnell, in her influential work on race and urban planning in Johannesburg, demonstrates that this was in fact a crucial strategy for racially segregating the urban working class and rehousing them at significantly differentiated standards of accommodation. ${ }^{14}$ The effect was destined to harden the compressed race-class character as well as spatial disconnection of "racial" difference in South Africa.

Revisiting the rich archival seam Susan Parnell had uncovered, as well as her extensive work on white housing in Johannesburg, this paper explores ideographically and at a micro-level, the genesis and completion of Johannesburg's first white housing scheme, the Jan Hofmeyr scheme, as a stand-alone project that was spatially located. The article explores local state dynamics, practices and discourses to account for the particular kind of civic social imaginary that shaped the project as well as the consequences thereof. In his work, Modern Social Imaginaries, Charles Taylor uses the term "social imaginaries" to capture the importance of ways in which:

people "imagine" their social existence; how they fit together with others; how things go on between them and their fellows; the expectations that are normally

9. Du Plessis, “Living in Jan Bom”, p 882.

10. Klausen, "Poor Whiteism", p 56.

11. P. Rich, "Race, Science and the Legitimation of White Supremacy in South Africa", 1902-1940, The International Journal of African Historical Studies, 23, 4 (1990).

12. Klausen, "Poor Whiteism", p 56.

13. See Klausen, "Poor Whiteism"; S. Klausen, "Women's Resistance to Eugenic Birth Control in Johannesburg, 1930-39, South African Historical Journal, 50, 1 (2004); Beavon, Johannesburg.

14. Parnell, "Public Housing as a Device", pp 584-602; Parnell, "Council Housing Provision". 
Du Plessis - Johannesburg's "model white housing scheme"

met and the deeper normative notions and images that underlie these expectations. ${ }^{15}$

The two key role-players in the design of the scheme, Dr A.L. Milne, Johannesburg's $\mathrm{MOH}$, and Lionel Leveson, a city councillor, each brought a distinctive vision to the white housing project. This can be accounted for partly in terms of the Weberian emphasis on disaggregating the bureaucratic and political functions of the state. ${ }^{16}$ But pressure brought by civil society organisations and the political influence of civil society lobby groups further moulded the civic imaginary that underpinned the scheme.

\section{Large-scale racial-spatial social engineering: Law and regulation}

The principal modernist instrument for city planning is the law. By the early 1930s, slum clearance in Johannesburg was regulated chiefly, but from the perspective of the medical officer of health, not particularly effectively, by the Local Government Ordinance of 1926. Provisions of the Housing Act, No. 35 of 1923, and the Native Urban Areas Act of 1923 were also used. In 1933, the possibility of a more effective instrument to combat the "slum peril" arose when the Cape Town City Council, in response to a request by the central state, produced a draft Slums Bill. ${ }^{17}$ Once this Bill was adopted, the three laws that principally produced the racially segregated geography of Johannesburg were in place. ${ }^{18}$

The slum problem, and the location of whites in slums, were matters causing disquiet among the enfranchised public. Reflecting their anxieties and playing up the petty tug-of-war between cities that attract readership to local newspapers, Johannesburg-based The Star expressed concern that Cape Town's city authority was taking the lead on the slums issue. It hoped that a newly launched civil society organisation (the Johannesburg Public Housing Utility Company) formed at the insistence of the Rotary Club, would advance the issue in Johannesburg. ${ }^{19}$

The implicit suggestion that the Johannesburg City Council, in particular the Department of Health, was not discharging its duties adequately led to a swift reply to the innuendos expressed in The Star. Signed by the chairman of the Public Health Committee, but clearly written in the style of the city's MOH, Dr H.L. Milne, the letter outlined the PHC's successes in relation to the slum problem in the four years prior:

15. C. Taylor, Modern Social Imaginaries (Duke University Press, Durham, 2005).

16. G. Poggi, Weber: A Short Introduction (Cambridge, Polity Press, 2006), p 119.

17. The Star, 13 September 1933. The article noted that "the conditions in some areas [in Cape Town] - as with us in Johannesburg - are notoriously discreditable, and with the present demand for employment as an additional incentive towards a general programme of slum clearance, there seems a likelihood that this may be undertaken after the measure becomes law".

18. Beavon, Johannesburg, p 95. These were the Native (Urban Areas) Act of 1923; the 1930 Amendment to the 1923 Act; and the Slums Act of 1934.

19. The Star, 13 September 1933. 
955 closing orders and 147 demolition orders had been obtained, affecting - that is, displacing - a "conservative estimate" of 30000 people. This figure refers to Africans displaced by the application of the 1923 Native Urban Areas Act, stark evidence of the scale of the racial and spatial re-engineering of the city that was taking place. ${ }^{20}$

The letter stated that the PHC was constrained in its task because obtaining closing or demolition orders from courts were cumbersome processes and involved delays. Orders could be obtained for individual [my emphasis] insanitary properties only, and were limited by the number of cases the courts could handle. ${ }^{21}$

A Public Health Sub-Committee on Slums and Housing was established to review the Draft Bill on the Elimination of Slums. ${ }^{22}$ In his report, Dr Milne noted that the bill was closely modelled on housing legislation in Britain. Milne supported legislation of this kind because it provided a link between the provision of (white) housing and slum clearance. ${ }^{23}$ He recommended local authority powers similar to those outlined in the British legislation, the Housing of the Working Classes Act of 1890, which allowed for the expropriation of "insanitary" or "unhealthy areas", 24 including built structures, and for the conversion of such areas into "healthy areas" by means of what were labelled "improvement schemes".25 While the Housing Act of 1923 gave local

20. Administrative logic separated the health and sanitation "slums clearance" concerns from the need to rehouse displaced black slum-dwellers. This was because the latter fell under the Native Housing Department, so Dr Milne's department did not have to concern itself with these matters. On this, see S. Parnell, "Racial Segregation in Johannesburg, South African Geographical Journal, 70, 2 (1988), pp 112-126.

21. The Star, 13 September 1933.

22. NASA, TAD, MJB, Volume 68, Legislation for Slums, Reports of the Public Works Committee, January to December 1933, "Report of the MOH to the PHC, prepared for the PHC meeting on 9 November 1933". The Sub-Committee comprised the chairman and the vice chairman of the PHC, as well as councillors Mrs M.E. Pemberton and $\mathrm{Mr}$ Lionel Leveson.

23. Parnell, "Council Housing Provision", argues persuasively that the impoverishment of this point of view is that the same logic did not extend to all racial groups; it was therefore a racial modernist imaginary.

24. See M.W. Swanson, "The Sanitation Syndrome: Bubonic Plague and Urban Native Policy in the Cape Colony, 1900-1909", The Journal of African History, 18, 3 (1977); Beavon, Johannesburg, pp 75-77. Swanson provides a broader exposition of the "sanitation syndrome" at the heart of colonial town planning. Beavon, Johannesburg, shows that the notion of an "unhealthy area" was a broad concept, referring to levels of water pollution and other factors providing the conditions for bubonic plague, including its pneumonic form, as well as other disease threats. However, as Beavon points out, while conditions of overcrowding and other health hazards did create health threats, there was also an aspect of moral panic, fuelled by the white middle class, about disease threats linked to multiracial slum areas or black areas, such as the case of the Coolie location in 1904.

25. National Archives of South Africa, Pretoria, (hereafter NASA), Transvaal Archives Department (hereafter TAD), Municipality of Johannesburg (hereafter MJB), Volume 68, Legislation for Slums, Reports of the Public Works Committee, "Report of the MOH 
authorities the power to expropriate land for housing purposes, these powers did not extend to existing insanitary areas. ${ }^{26}$ This was important, given that white slum conditions occurred in specific areas and were not scattered across the entire city. ${ }^{27}$

In his report, Milne went on to identify "European slum conditions" as existing in Fordsburg, portions of Jeppe, Doornfontein and Newlands. In these areas, "Europeans [were] congregated in rooms and buildings, as often as not, in juxtaposition to coloured persons, Asiatics and a certain number of natives not yet removed ... under the Natives (Urban) Areas Act". He acknowledged that general slum conditions (as opposed to European slum conditions) also existed in Prospect, the Malay Location, Denver and in Doornfontein, south of the railway line, as well as in the townships already mentioned. In order to justify his focus, which privileged the removal and re-housing of whites from slums, in this same report he stated that "these problems are primarily in connection with Native occupation and do not affect White occupation and will gradually be remedied as native housing is made available at Orlando Township, where progress is advancing rapidly".

Having rejected subsidised housing provision for whites in 1927, Dr Milne now supported it, because Johannesburg, he stated, had developed a "White Housing problem due to the influx of poor European families whose wages were too low to afford existing rentals for decent cottages". ${ }^{28}$

\section{White housing: Moral concerns about white poverty}

Milne's enthusiasm for the proposed Slums Act drew strong support from another corner. Lionel Leveson was a city councillor, a member of the PHC, and a director of the Johannesburg Housing Utility Company (JHUC) - a non-profit corporation that aimed to buy up large parts of slum areas, clear them, and then initiate housing projects. This it hoped to achieve by raising private finance and gaining access to state sub-economic housing funding. ${ }^{29} \mathrm{He}$ was particularly interested in social rehabilitation programmes for whites.

It was Leveson who put flesh on the bare bones of the housing scheme idea when, at a special meeting of the PHC, he proposed the replacement of slum areas

to the PHC, prepared for the PHC meeting" 9 November 1933.

26. Refer to footnote 24 .

27. NASA, TAD, MJB, Volume 68, Legislation for Slums, Reports of the Public Works Committee, January to December 1933, “MOH's Report to the PHC for period 26 August to 28 September 1933, prepared for the PHC meeting on 11 November 1933".

28. NASA, TAD, MJB, Volume 68, Legislation for Slums, Reports of the Public Works Committee, 1933, "MOH's Report to PHC for period 26 August to 28 September 1933", p 15.

29. While utility companies and building societies required local authority support to access state finance, they were also able to raise private monies. 
with "garden suburbs". He phrased his resolution so as to attract broad council support, explaining it was imperative that:

... with a view to the alleviation of unemployment, ${ }^{30}$ the elimination of disease centres, the amelioration of the social and economic conditions of certain classes and the general improvement of the economic, moral and hygienic status of the city, the Council do immediately embark upon a comprehensive slum clearance and white housing scheme. ${ }^{31}$

His comprehensive proposal called for a census of slum areas; drafting provisions for purchasing properties; submitting a state housing loan application; inviting architectural designs for garden suburbs in slum areas; and selecting a suitable site for the first scheme. He further proposed including budgetary funds for the appointment of a manager "to control the collection of rentals and general cleanliness of dwellings, once erected, on the Octavia Hill system"32 and encouraged the council's cooperation with public utility societies.

Leveson had done his homework. For some time, he had been trying to persuade the city council of the viability of white housing schemes. Benefit societies were already operating in Cape Town. ${ }^{33}$ To promote an apartment block scheme, Octavia Hill, which the JHUC proposed to build in Fordsburg, ${ }^{34}$ and for which it needed council support, he produced a leaflet, "To Hell with Slums", in which he outlined the main tenets of his approach, including his understanding of white poverty as a sociological rather than a biological matter:

I realise that slums have been created by this influx of poor whites; but ... these same poor whites are not inveterate or hereditary slum dwellers ... there is material in these same poor whites, and particularly their children, from which can be built a race of which not only South Africa but the whole world may be proud. It must be borne in mind that they have in their veins the blood of explorers, conquerors, and pioneers, and that we have a legal, moral and sociological duty to ensure that they be provided with the institutions adapted to their changed mode of life and charged with the potentialities of re-creating in them the splendour of previous generations. Without being unduly idealistic, I

30. Here Leveson proposes that municipal housing schemes will provide job opportunities for unemployed whites, in line with the government's "civilised labour" policy.

31. NASA, TAD, MJB, Volume 68, Legislation for Slums, Reports of the Public Works Committee, January to December 1933, "Proposals by Councillor Leveson, prepared for a Special Meeting of the Public Health Committee meeting on 16 November 1933".

32. NASA, TAD, MJB, Volume 68, Legislation for Slums, Reports of the Public Works Committee, January-December 1933, "Proposals by Councillor Leveson, prepared for a Special Meeting of the Public Health Committee meeting on 16 November 1933".

33. NASA, TAD, MJB, Minutes of the Conference on Housing and Slum Elimination, Cape Town, 16-17 January 1936; Public Health Committee Meeting, 27 February 1936.

34. NASA, TAD, MJB, Volume 74, Reports of PHC, 1936, "Johannesburg Housing Utility Company: Housing Loan", in "Report of the Town Clerk, 9 January 1936". 
Du Plessis - Johannesburg's "model white housing scheme"

feel that the first step, and the vital step, in this direction is to house them under proper conditions and thereafter by sympathetic management to accustom them to these changed conditions and to make them worthy, industrious, beneficial citizens. $^{35}$

The reference to "pioneers" and "changed mode of life" shows that Leveson was alert to the "ethnic" nature of the poor white problem and the difficulties of Afrikaans-speaking whites who had become dislodged from rural livelihoods and had no appropriate skills for an industrial economy.

The Slums Act was adopted in 1934. Milne was concerned that dealing with insanitary properties on a case-by-case basis would be costly and time-consuming. ${ }^{36}$ In addition, the standard of alternative housing for displaced (white and coloured) persons would place a burden on the council, given that the Slums Act required each family to have its own cooking and bathing facilities. Milne thought it unlikely that private enterprise would provide accommodation at a rate affordable to the white poor. To accommodate the act's provisions while also enabling council to deal with slum areas rather than individual insanitary properties, the $\mathrm{MOH}$ recommended that the local authority and public utility societies provide alternative housing. Timing was urgent, because the White Housing Survey of 1933 showed that 1121 white families in Johannesburg were in need of housing. ${ }^{37}$ This sealed the plan to go ahead with the proposed housing scheme.

\section{Clearing the space: Race, class and civil society}

A stretch of land on the Brixton Ridge, known as Bokrand or Panorama Ridge, situated directly to the north of Caroline Street in Brixton and to the west of Vrededorp, was identified. This decision was based on the criteria that the site had to be close to the tenants' workplaces and that inexpensive transport, water, light and gas had to be available. ${ }^{38}$ The Star described it as one of the "healthiest sites in Johannesburg". ${ }^{39}$ Fortuitously, the land was already owned by the council. Here a model township of 200 houses, specifically for letting purposes, would be built at a projected cost of $£ 100,000 ;{ }^{40}$ and it was agreed to name it after Jan Hofmeyr. ${ }^{41}$

35. L. Leveson, To Hell with Slums, Publication of the Johannesburg Housing Utility Company, 1933, cited in Parnell, “Council Housing Provision”, p 54.

36. NASA, TAD, MJB, Volume 70, Reports of the Public Works Committee, July to December 1934, "Special Report by MOH to PHC on the Slums 1934, more particularly in connection with its suitability for application to insanitary areas and expropriation by the council of such areas, 14 September, 1934".

37. NASA, TAD, MJB, Volume 68, Reports of the Public Works Committee, 1933, "A Survey of White Housing Needs".

38. NASA, TAD, MJB, Volume 70, Reports of the Public Works Committee, July to December 1934, "Special Committee re Slums and Housing".

39. The Star, 10 January 1934; 21 January 1934; 31 January 1934, all cited in Parnell, "Public Housing as a Device”, p 310; see also Parnell, “Council Housing Provision”.

40. NASA, TAD, MJB, Volume 70, Reports of the Public Works Committee, July to 
Councillor Leveson had been concerned about the general improvement of the broader area for some time and was in discussion with another civil society organisation, this time one with largely Afrikaans-speaking membership, Die Agterbuurtbestryders (Slum Fighters). Established in 1914, this organisation aimed to promote awareness and disseminate information about the living conditions of poverty-stricken Afrikaners in Johannesburg by means of films and lectures. Much of its work was concentrated in the adjacent suburb of Vrededorp. ${ }^{42}$

Vrededorp was the site where many of Johannesburg's indigent white Afrikaner transport riders settled when deprived of their livelihood with the development of rail networks. Other white residents arrived when removed from the Brickfields slum because of a building project there; they had received stand licences from Paul Kruger's ZAR when the suburb was proclaimed in $1893 .^{43}$ Beavon argues that the proclamation of Burghersdorp and Vrededorp sealed the fate of Johannesburg's western suburbs in terms of class. Given that both suburbs became home to impoverished Afrikaners, more prosperous residents moved north; and as for the east, it was already more affluent. ${ }^{44}$ The housing scheme would therefore be located within a broader area that was home to the Afrikaner poor and included slum yards.

Public announcement of the plan to erect the housing scheme meant that competing claims to the land and its use surfaced. In his report to the Public Health Committee, Dr Milne explained that a lawyer's letter had been received from a Mr I.I. Hazaree - on behalf of Abram Nkue, Simon Malungoane, Rudolph Malatze, Hendrick Malatze, Isaac Manamela, Lota Lebete, Jacob Mashimane and others. It read:

The position is that for a considerable number of years, and in fact from the time of the late President Paul Kruger, there has been in existence an outspan ${ }^{45}$ near

December 1934, "Special Committee re Slums and Housing".

41. NASA, TAD, MJB, Report by the City Engineer's Department to the Public Health Committee, "Housing Scheme, Jan Hofmeyr Township", prepared for Public Health Committee Meeting, 26 September 1935. This was in honour of the former administrator of the Transvaal and at the time the minister for Education, Interior \& Health in the so-called fusion government. The scheme was referred to variously as the Brixton Ridge Housing Scheme; Brixton Housing Scheme; Housing Scheme North of Vrededorp; White Housing Scheme; Cottesloe Housing Scheme and Bokrand Housing Scheme.

42. Stals, Afrikaners in die Goudstad, p 23. The Johannesburg Housing Utility Company was proposing to erect an apartment block in Fordsburg, a suburb adjoining Vrededorp and also home to large numbers of poor Afrikaners. In March 1914, the organisation known as Die Agterbuurtbestryders officially pledged its support to the Johannesburg Housing Utility Company.

43. Beavon, Johannesburg, p 64.

44. Beavon, Johannesburg, p 61.

45. An "outspan" was a gathering area designated as an intermediate stop for persons conveying fresh produce from farms to city markets. 
the Municipal compound between Vrededorp and Brixton, which had been made use of by these native farmers to bring in their produce, etc. It appears that lately the police have raised objection to these farmers outspanning in this place, and in fact prohibited and warned them not to do so in the future. They have gone so far as to put up a notice from Monday the $26^{\text {th }}$ day of March 1934, prohibiting outspanning to take place in that area. This action ... has greatly perturbed these farmers, and has affected them very seriously in their business and livelihood.

In his report, the $\mathrm{MOH}$ dismissed the claims made in this letter. His recommendation to the PHC was curt - the outspan had never been legal. Because plans to construct a white housing scheme on the site adjoining the (un-official) outspan had now been approved, the activities of the black farmers would no longer be tolerated. He went on to explain:

There is no legal outspan on the ground in question ... It is well known that native farmers have been in the habit of using this ground as an outspan and as a place for sale of farm produce to natives largely, and since no appreciable nuisance has occurred and there being no residences in the immediate vicinity, no steps have been taken beyond the erection of notice boards to prevent native hawkers occupying the ground. The site adjoins the Council's ground on which it is proposed by the slums committee to establish a considerable White Housing Scheme ... Apparently the police authorities have warned the persons who have been in the habit of outspanning here that outspanning in future will not be tolerated. It is considered that the Police Authorities should be supported in their endeavour to carry out the law in regard to outspanning. As a matter of fact, it is very difficult to control properly outspans anywhere within the boundaries of the Municipal Area. ${ }^{46}$

This constituted the closing of an informal "commons", bringing the city under more meticulous racial-spatial control. A recommendation by the Special Committee on Slums and Housing, supported by the Town Planning Committee, soon followed asking for the Vrededorp compound to be closed. ${ }^{47}$ This too had been a long-standing issue, only acted upon now. ${ }^{48}$ It was evident, therefore, that the housing scheme,

46. NASA, TAD, MJB, Volume 69, Reports of the Public Works Committee, January to June 1934, “MOH's Report to the Public Health Committee for period 5 to 26 April 1934, prepared for the Public Health Committee meeting on 26 April 1934".

47. NASA, TAD, MJB, Volume 70, Reports of the Public Works Committee, July to December 1934, "Town Planning Committee to Special Committee on Slums and Housing, 13 October 1934".

48. As early as 1925 , the Vrededorp ratepayers had sent a deputation to the prime minister, J.B.M. Hertzog, to request the removal of the Vrededorp compound on the grounds that the large crowds of Africans who congregated on Sundays in open spaces created a disturbance and tainted the image of the suburb, which was widely regarded as a rowdy and unwholesome neighbourhood. See "The Vrededorp Location", Rand Daily Mail, 8 January 1925, cited in Parnell, "Council Housing Provision". 
which would only be built on a portion of the vacant land, rendered the entire area a white space.

However, the $\mathrm{MOH}$ resisted pressure from city council to advance the "whitening" of the Vrededorp area. When requested to conduct a thorough investigation of the "conditions existing in the Malay location with a view to action being taken in terms of the Slums Act 1934", he recommended that no action be taken, arguing that most residences in the Malay Location complied with city laws and by-laws. As pressure mounted on the $\mathrm{MOH}$ from various council committees, including his own, as well as from individual councillors (in all likelihood including Leveson) about "the necessity of clearing once and for all certain insanitary areas in the city", where racial segregation was deemed necessary, ${ }^{49} \mathrm{Dr}$ Milne chose to interpret his brief more narrowly as a legal and public health matter. ${ }^{50}$

The class interests of white property owners (who had political franchise) produced another set of contestations, with complaints that the siting of a subsidised housing scheme on the proposed land devalue their nearby properties. The Western Suburbs Property Owners Association (WSPOA) protested that it had been assured that the land north of Caroline Street would be developed into a park for leisure and recreation purposes. ${ }^{51}$ Moreover, after listening to a talk by Lionel Leveson on slums they reported that it was "undesirable for a venture of this description, viz: the building of houses to let at $10 /-$ and $12 / 6$ weekly ... to be erected in this district". 52 Complaints were also received from the Richmond, Sunnyside, Cottesloe, and Braamfontein Werf Ratepayers and Tenants Association. ${ }^{53}$

Yet, Dr Milne, an appointed official, a bureaucrat who did not have to worry about re-election, urged council to adopt a "bold policy" and to "take no undue cognisance" of petitions lodged against its housing schemes by "disgruntled rate payers whose grievance is not so much depreciation of their properties as non-

49. NASA, TAD, MJB, Volume 71, Reports of the Public Works Committee, 1935, "Malay Location", p 8, in "MOH's Report to the PHC, prepared for the Public Health Committee meeting on 31 January 1935.

50. NASA, TAD, MJB, Volume 70, Reports of the Public Works Committee, July to December 1934, "Special Report by Medical Officer of Health to Public Health Committee on the Slums Act 1934, more particularly in connection with its suitability for application to insanitary areas and expropriation by the council of such areas, 14 September 1934."

51. A petition was signed by 1000 residents. See S.M. Parnell, "Land Acquisition and the Changing Residential Face of Johannesburg, 1930-1955", Area, 20, 4 (December 1988), p 310; Parnell, “Council Housing Provision”.

52. NASA, TAD, MJB, Volume 70, Reports of the Public Works Committee, July to December 1934, "Report of the Town Clerk to Public Health Committee, prepared for Public Health Committee Meeting, 29 November 1934".

53. NASA, TAD, MJB, Volume 74, Reports of the Public Health Committee, 1936, "SubEconomic Housing Scheme, Jan Hofmeyr, Engineer's Department, prepared for the Public Health Committee meeting, 30 January 1936". 
appreciation" of the wider situation. ${ }^{54}$ However, when an opportunity arose, the WSPOA's concerns were accommodated. ${ }^{55}$

\section{A "model white improvement scheme" in the civic imaginary}

As the Johannesburg City Council's first white housing scheme, Jan Hofmeyr had to be a model enterprise. It was decided that the proposed housing scheme would be a freestanding development, because land in Johannesburg (compared to prices in Britain) was neither expensive nor scarce. The alternative of constructing apartment blocks was seen as possibly producing conditions of despair that could foster extreme political movements. This perspective was based on the expertise of Sir Raymond Unwin - a former president of the Royal Institute of British Architects and a key influence in the working class housing movement in England - about the social and political advantages of free-standing homes in garden suburbs. ${ }^{56}$

The standard of housing offered by the city council was racially differentiated. ${ }^{57}$ Housing developments for Africans were regulated by native location regulations, and did not fall under the Slums Act. The aspirational quality of the Jan Hofmeyr scheme is therefore most evident when contrasted with housing provision for so-called "coloured" people. ${ }^{58}$ Parnell argues the main difference between white and coloured council housing was not so much the structures themselves, ${ }^{59}$ although there were vast cost disparities, ${ }^{60}$ but the levels of infrastructure development and

54. NASA, TAD, MJB, Volume 70, Reports of the Public Works Committee, July to December 1934, "Special Report by the MOH to PHC on the Slums Act 1934, more particularly in connection with its suitability for application to insanitary areas and expropriation by the council of such areas, 14 September 1934".

55. The SAR\&H contacted the city council proposing to exchange a piece of land that the SAR\&H owned to the north of the Brixton cemetery in exchange for a portion of Milner Park that was under lease to the Witwatersrand Agricultural Society. The outlay of the housing scheme was thus redesigned "to provide as large an open space between the township of Brixton and the houses it was proposed to erect under the scheme". After the plans were approved, the SAR\&H decided to withdraw its offer. Council suggested that instead the SAR\&H should accept stands 44 to 72 in Langlaagte North Township (an area of 3.6 acres) in exchange for the Brixton grounds, to which the SAR\&H agreed. See TAD, MJB, Volume 71, Reports of the Public Works Committee, 1935, "Exchange of Ground - SAR\&H, Report of Town Clerk to Public Health Committee, prepared for Public Health Committee Meeting, 25 April 1935.

56. NASA, TAD, MJB, Volume 71, "Report of the City Engineer on the Bertrams Housing Scheme", 25 April 1935.

57. Parnell, “Council Housing Provision”, p 78.

58. Parnell, "Council Housing Provision”, p 78.

59. Parnell, "Council Housing Provision", p 78. In 1966, the average cost for a house for whites was $£ 250$ - 450 , against $£ 50$-350 for a house for coloureds. This is probably explained by the use of civilised (white) labour for the white housing scheme as well as the infrastructure development.

60. Parnell, "Council Housing Provision", p 78. Parnell states that when picture railings were infested by bugs, the picture railings in the white council houses were replaced 
the aesthetic elements included for white housing projects. The Coronationville scheme, for example, did not have streets with kerbs, nor were trees planted.

The original budget for the proposed scheme made provision for servicing the white housing estate with tarred roads, storm water drainage, trees, kerbs, lighting and a communal hall. ${ }^{61}$ Streets were designed to be short, curved and tree-lined. Most properties were placed so that they would overlook a small piece of grass or a public space. Units were to be built of red brick, with corrugated iron roofs and brick chimneys. There would be two-bedroom (approximately $55 \mathrm{~m}^{2}$ ) and three-bedroom (approximately $75 \mathrm{~m}^{2}$ ) units, each on its own stand or plot, enclosed by a wire-mesh fence, as well as a small number of two-bedroomed, semi-detached homes. ${ }^{62}$ Elevation, "considered necessary to break the monotonous appearance where houses are set out unavoidably in long rows" was a central feature of the design. ${ }^{63}$ The Jan Hofmeyr scheme was therefore designed to enable wholesome living, with play facilities for children in the parks, private gardens so that residents could take up the hobby of gardening, and to promote community solidarity by sharing certain facilities.

Symbolically, the scheme represented a change in the way that Johannesburg housed the white poor, thereby signalling its modernity. At the Ideal Homes Exhibition held in September 1935, organised by the Rand Daily Mail, the proposed white housing scheme was the central feature of the city council's model display. Yet, this was a thoroughly racial modernity and placed beside the scale model of the Jan Hofmeyr scheme was another of the model homes for Africans, probably representing the Orlando scheme, situated in Johannesburg's newly founded native townships. This demonstrated the extent to which differential standards in housing provision for different racial groups were interwoven in the civic social imaginary. ${ }^{64}$ The civic imaginary comprised two parts, the first being the planned, orderly, racially segregated and differentiated city; the second its social reformist aspirations for white residents. This thoroughly racialised imaginary was reflected in the third scale model on display - beside the model of the white housing scheme was one of an ideal nursery.

by more expensive copper tubing, while picture railings were simply removed from houses for coloureds.

61. Parnell, "Council Housing Provision", p 78; Du Plessis, "Living in Jan Bom”.

62. NASA, TAD, MJB, Volume 71, "Supplementary Report to the Health Committee, City Engineer's Department", in "Report prepared for a Special Public Health Committee Meeting on 25 April 1935".

63. The elevation of homes required additional supporting walls and since the original tender did not include a bill of quantities, more materials than were budgeted for were required. Situated on a ridge, the building contractors also found more rock than was anticipated. This had to be removed to elevate the houses correctly.

64. NASA, TAD, MJB, Volume 69, Reports of the Public Works Committee, January to June 1934, “Ideal Homes Exhibition, MOH's Report to the Public Health Committee for period 26 May 26 to 28 June 1934, prepared for the Public Health Committee meeting on 28 April 1934", p 8. 
The scheme also carried another symbolic load. The city's town planner gave the scheme a cultural inflection, naming the streets after flowers, and using Afrikaans versions of these names. ${ }^{65}$ And significantly, the scheme was named after Jan Hofmeyr, an Afrikaner (but not a nationalist). These were attempts by the PHC, with its predominantly English-speaking membership, to give some cultural recognition to the Afrikaans-speaking community who would be the majority of the scheme's first beneficiaries.

In order to mark the scheme's symbolic significance, the city engineer recommended the erection of granite drinking fountains in the two parks in the scheme, each with a suitable inscription. ${ }^{66}$

\section{Eroding the foundations: Building a model village at all costs}

Translating a utopian design into bricks-and-mortar proved challenging. The scheme seems to have been planned in haste, ${ }^{67}$ and it soon became clear that many costly items had not been included in the budget; others had simply not been anticipated. Additional money was needed for variations in the elevation of the houses. ${ }^{68}$ With costs running at just $£ 2500$ below the loan amount of $£ 100000$, no money was available for the parks ${ }^{69}$ or laying down the roads. The tender was for construction work only and did not include services and fencing. The city engineer expected total costs to exceed the loan amount by $£ 25000$. To offset costs, he suggested that proposed rents be increased. ${ }^{70}$ This marks the first step away from the scheme's main aim, which was to provide subsidised housing for whites from slum areas. In order to

65. A.J. Smith, Johannesburg Street Names: A Dictionary of Street, Suburb and Other PlaceNames, Compiled to the end of 1968 (Juta, Cape Town, 1971), p 238. Mr F. Strugnell is reported to have requested an Afrikaans catalogue from a seedsman. Street names include Aandblomstraat (Evening Flower Street); Suikerbosstraat (Protea Street); Leeubekkielaan (Snapdragon Avenue); Gousblomstraat (Marigold Street); Sonneblomstraat (Sunflower Street), Kosmossirkel (Cosmos Close) and Katjiepieringstraat (Gardenia Street).

66. NASA, TAD, MJB, Volume 72, Reports of the Public Works Committee, 1935, "Report to Public Health Committee, City Engineers' Department, prepared for special meeting of the Public Health Committee on 13 August 1935".

67. NASA, TAD, MJB, Volume 70, Reports of the Public Works Committee, July to December 1934, "Special Committee re Slums and Housing".

68. The elevation of homes required additional supporting walls and since the original tender did not include a bill of quantities, more materials than were budgeted for were required. Situated on a ridge, the building contractors also found more rock than was anticipated. This had to be removed in order to elevate the houses correctly.

69. NASA, TAD, MJB, Volume 76, Reports of the Public Health Committee, 1936, "Jan Hofmeyr Township: Progress Report. Report of the Medical Officer of Health, prepared for the Public Health Committee meeting, 20 July 1936".

70. NASA, TAD, MJB, Volume 72, Reports of the Public Works Committee, 1935, "Contract No. 1537: 200 houses for the white housing scheme, Brixton Ridge”, in Report of the City Engineer's Department, Report No.12/35, prepared for the special meeting of the Public Health Committee on 17 June 1935". 
complete the scheme, an additional loan for $£ 15000$ had to be secured ${ }^{71}$ to cover increased costs for building material and wages, demonstrating that the civilised labour policy became a constraint on white working class housing provision and slum clearance. ${ }^{72}$ Furthermore, no provision had been made for office space for the Jan Hofmeyr scheme's director of housing or the manageress, and one of the houses had to be reserved for that purpose. This meant a further adjustment of rental income calculations that prospective tenants would have to make good..$^{73}$ The symbolic dimensions of the project thus triumphed over its original purpose. It was an expensive project, even although the council already owned the land.

Despite financial constraints, there is evidence that Dr Milne pushed up the standards for alternative housing provision. The scheme's director of housing recommended the installation of a shed and a food cupboard in each dwelling - a necessity to "ensure neatness", a decision made following an exploratory visit to the Cape Town scheme. ${ }^{74}$ At this point it was the Cape Town local authority that had the most extensive experience of public housing, albeit not council housing. ${ }^{75}$ At a conference on the Slums Act, held a year after its implementation, Dr Milne submitted specifications for a shed ${ }^{76}$ and a cupboard, ${ }^{77}$ to be included in the revised act. Once adopted, he authorised the inclusion of these facilities post facto in the Jan Hofmeyr scheme - even though it was already way over budget - on the grounds that these were standards stipulated by the Slums Act. He also recommended that the minimum requirements of re-housing should include a separate kitchen, bathroom and WC, and

71. NASA, TAD, MJB, Volume 72, Reports of the Public Works Committee, 1935, "Contract No. 1537: 200 houses for the white housing scheme, Brixton Ridge", in Report of the City Engineer's Department, Report No. 12/35, prepared for the special meeting of the Public Health Committee on 17 June 1935".

72. Parnell, “Council Housing Provision”, p 46.

73. NASA, TAD, MJB, Volume 73, Reports of the Public Works Committee, 1936, "MOH's Report to Public Health Committee for period 31 January to 27 February 27 1936, White Housing Scheme, Jan Hofmeyr Township".

74. NASA, TAD, MJB, Volume 72, Reports of the Public Health Committee, 1935, Report of the Medical Officer of Health, 29 June 1935, "Director of Housing: Visit to Cape Town", prepared for the Public Health Committee meeting.

75. See A. Teppo, The Making of a Good White: The Historical Ethnography of the Rehabilitation of Poor Whites in a Suburb of Cape Town (Helsinki University Press, Helsinki, 2004).

76. He stated that the shed "should be too small for use as a boy's room [servant's quarters], should not be provided with windows; should be large enough for the storage of a push bicycle or motor cycle and a pram with odds and ends". Parnell indicates that this was necessary because there could not be official support for low earning whites to employ domestic servants. See Parnell, "Council Housing Provision", p 77.

77. NASA, TAD, MJB, Volume 73, Reports of the Public Health Committee, 1935, "Housing and Slum Elimination" in "Report of the $\mathrm{MOH}$, prepared for the Public Health Committee meeting, 14 November 1935". Milne even goes as far as citing the latest regulations in Britain pertaining to the minimum amount of space for a living room (unspecified in the Slums Act) and suggest that this specification be added. 
cited the latest regulations in Britain pertaining to the minimum amount of space for a living room (unspecified in the Slums Act) suggesting that this specification be added..$^{78}$ He now also supported the idea of apartment blocks as "suitable centres for the rehabilitation of families accustomed to living under slum conditions". This form of housing had previously been ruled out, possibly because of submissions by the housing utility societies. ${ }^{79}$

Clearly, the rise of expenditure in all these cases undercut the council's ability to provide affordably low rentals - the Johannesburg scheme's original raison d'être.

\section{Regimes of care: More than just landlord and tenant}

With construction work well under way early in 1936, the management model and tenant selection process had to be considered. Leveson had originally proposed that the Octavia Hill model be followed, but little discussion had taken place since. Two reports prepared for the Public Health Committee (PHC) explored the model and secured support for it.

Meanwhile, Lionel Leveson's Johannesburg Housing Utility Company (JHUC) had put in a request to the PHC to obtain on its behalf a sub-economic loan from the Central Housing Board for the apartment block in Fordsburg. ${ }^{80}$

Preparing a report on the role of housing utility societies for the PHC's consideration of the JHUC's request, the town clerk, Mr A. Spencer, gave the request his approval, citing Sir E.D. Simon, author The Anti-Slum Campaign. Simon maintained:

[Housing utility societies] have shown a social conscience much more highly developed than that of most municipalities, in that they have taken great trouble to select the tenants who most needed help, that is to say, those with large numbers of children. ${ }^{81}$

78. NASA, TAD, MJB, Volume 73, Reports of the Public Health Committee, 1935, "Housing and Slum Elimination", in "Report of the $\mathrm{MOH}$, prepared for the Public Health Committee meeting, 14 November 1935".

79. NASA, TAD, MJB, Volume 73, Reports of the Public Health Committee, 1935, "Housing and Slum Elimination", in "Report of the $\mathrm{MOH}$, prepared for the Public Health Committee meeting, 14 November 1935".

80. In the minutes of the conference on Housing and Slum Elimination held in the City Hall, Cape Town on 16-17 January 1936, to review the Slums Act of 1934, which had been in operation for a year, Leveson is reported to have explained the difficulties his utility company faced to obtain a loan. He said that unless they received more sympathetic treatment, there was little hope of utility companies functioning in the Transvaal. He went as far as to suggest that such benefit societies be empowered to bypass local councils and make applications directly to the Central Housing Board.

81. NASA, TAD, MJB, Volume 70, Reports of the Public Works Committee, July to December 1934, "Report of Town Clerk to Special Committee re Slums and Housing, 
Spencer noted that such schemes were generally run on Octavia Hill principles. He drew to the committee's attention to the problem of the "undesirable" tenant, frequently encountered in relation to social housing matters. Applicants whose lifestyles had to such an extent been shaped by the experience of poverty and slumliving, and who therefore were deemed difficult to "rehabilitate" - or, in the parlance of the period, "uplift" - were refused access to alternative housing by local authorities. However, these "undesirable tenants" were likely to remain a problem, contributing to re-creating slum conditions. In Spencer's view there was a need to find a place for "undesirable" tenants in the system. Spencer expressed the hope that public utility societies would be well placed to provide assistance in this regard, ${ }^{82}$ given Octavia Hill's counsel that "you can hunt the poor about from place to place, rout them out of one place and drive them to another; but you will never reach the poor except through people who care about them". ${ }^{83}$

More support for the Octavia Hill system came from the director of housing, a Mr Crothall, who was most impressed by Margaret Hurst, trained on the Octavia Hill model, who was manageress in Cape Town. Her responsibilities were tenant selection; supervision of general maintenance and repairs; monitoring of living conditions and hygiene; and investigations into rent arrears. Crothall reported that Hurst spent her time "inculcating Octavia Hill ideas and ideals to the tenant" and was able to achieve significant levels of social upliftment. He put her success down to a "combination of a trained intellect allied to an understanding of mind and heart applied to the problems of the poor", and that this in turn had the "inevitable result, i.e. progress" ${ }^{84}$

Having decided on the Octavia Hill model for the Jan Hofmeyr scheme, Leveson proposed that the two requirements for a manageress were bilingualism and the appropriate training (as provided to an Octavia Hill housing manager). The kind of grassroots work he did as an elected politician and civil society activist meant that he was more in tune with the communities he was serving. Milne was less concerned about finding such a candidate, but placed the advertisement. Eighteen applications were received and by March 1936 a Ms D. Miskin, who was trained in Britain (and therefore highly unlikely to be able to speak Afrikaans) took up her position. ${ }^{85}$ She

13 October 1934".

82. NASA, TAD, MJB, Volume 70, Reports of the Public Works Committee, July to December 1934, "Report of Town Clerk to Special Committee re Slums and Housing, 13 October 1934".

83. This statement was made by an Octavia Hill spokesperson in giving evidence before the Select Committee appointed by the British parliament in 1882. See TAD, MJB, Volume 70, Reports of the Public Works Committee, July to December 1934, "Report of Town Clerk to Special Committee re Slums and Housing, 13 October 1934".

84. NASA, TAD, MJB, Volume 72, Reports of the Public Health Committee, 1935, "Director of Housing: Visit to Cape Town", in "Report of the Medical Officer of Health, prepared for the Public Health Committee meeting, 29 June 1935.

85. See J. Robinson, "Octavia Hill Women Housing Managers in South Africa: Femininity and Urban Government”, Journal of Historical Geography, 24, 4 (1998) pp 459 and 
would also be responsible for Octavia Hill training, and a few houses at Jan Hofmeyr were set aside for her trainees, once again reducing the number of homes available for rental. ${ }^{86}$

A hire agreement between council and tenants was drafted. Special provisions included (i) cleanliness; (ii) the right of the $\mathrm{MOH}$ to gain entry to the cottages for inspection purposes at all times, and (ii) a prohibition on bringing any item of furniture that had been purchased on a hire purchase agreement onto the premises if any part of the agreement was still unpaid. Exceptions to this rule were subject to the consent of the $\mathrm{MOH} .{ }^{87}$ In addition, there were restrictions on visitor access, subletting and using any rooms other than designated bedrooms as sleeping quarters. Tenants had to undertake to meet the requirements of the Slums Act at all times, i.e. to ensure that they did not create slum conditions in their cottages. ${ }^{88}$

The clause on furniture caused a fiery debate among members of the PHC. In its first draft, the clause stated that no furniture purchased on a hire-purchase agreement that was not fully paid was allowed on the premises. Some members of the committee felt that this clause was unfair, arguing that most people bought furniture in this way. Mr Leveson, however, countered that the problem of subsidised white housing was not merely a question of "landlord and tenant", and it was the duty of the city council to "assist in the rehabilitation of persons evicted from slum premises". The revised clause was the result of a compromise agreement that was reached. ${ }^{89}$

By 13 June 1936, as many as 860 applications had been received. Formal selection criteria were:

- tenants had to be white; and

- earn no more than $£ 20$ per month.

465.

86. Robinson, “Octavia Hill Women Housing Managers", p 466. A Ms Miskin was assigned to the Jan Hofmeyr township. Here she also trained a few student trainees at a time when the programme instituted by the Department of Health was inspired by the Octavia Hill model. This programme required two years at university and two practical years. Robinson notes that Miskin was assigned a few houses for training purposes.

87. NASA, TAD, MJB, Volume 76, Reports of the Public Health Committee, 1936, "Jan Hofmeyr Township: Allocation of Houses under Housing Schemes" in "Report of the Medical Officer of Health, prepared for the Public Health Committee meeting on 25 June 1936.

88. NASA, TAD, MJB, Volume 74, Reports of the Public Health Committee, 1936. "White Housing: Letting Agreement", in "Report of the Town Clerk to Public Health Committee, prepared for the Public Health Committee meeting on 12 February 1936".

89. NASA, TAD, MJB, Volume 74, Reports of the Public Health Committee, 1936. "White Housing: Letting Agreement", in "Report of the Town Clerk to Public Health Committee, prepared for the Public Health Committee meeting on 12 February 1936". 
However, given the large pool of applicants, the first 116 applicants were approved, ${ }^{90}$ after the exclusion of applicants who:

- could afford an economic rent;

- could not pay a sub-economic rent;

- who were either old or young couples without families or dependents; and

- whose "household habits [were] not considered satisfactory". 91

Successful applicants had to comprise a balance of:

- employees of the municipality, government, SAR\&H and private persons or firms, with a reasonable proportion from each;

- a reasonable number from premises scheduled as major or minor slums;

- a selected number whose personal habits and conduct appeared to be such as would set a higher standard of living. ${ }^{92}$

Support for the last category was derived from the Octavia Hill principle of rehabilitation by means of providing a good example. On the exclusion of applicants with unsatisfactory household habits, the report noted:

We have to bear in mind that the Council expects a "Model Village" and as "silk purses cannot be made out of sow's ears, every endeavour has been made to use discretion in the selections. ${ }^{93}$

Although this appears to run counter to the Octavia Hill sentiment expressed in an earlier report that the poor could only be rescued through "loving care", it would seem that this particular task would be left to the housing utility companies.

The majority of applicants were visited at their homes by either the manageress or the director of housing. Of the first 116 tenants approved, ${ }^{94}$ a large

90. While the report stated that 115 tenants were approved, the list of approved tenants actually numbered 116 .

91. NASA, TAD, MJB, Volume 76, Reports of the Public Health Committee, 1936, "Jan Hofmeyr Township: Allocation of Houses under Housing Schemes", in "Report of the Medical Officer of Health, prepared for the Public Health Committee meeting on 25 June 1936".

92. NASA, TAD, MJB, Volume 76, Reports of the Public Health Committee, 1936, "Jan Hofmeyr Township: Allocation of Houses under Housing Schemes", in "Report of the Medical Officer of Health, prepared for the Public Health Committee meeting on 25 June 1936".

93. NASA, TAD, MJB, Volume 76, Reports of the Public Health Committee, 1936, "Jan Hofmeyr Township: Allocation of Houses under Housing Schemes", in "Report of the Medical Officer of Health, prepared for the Public Health Committee meeting on 25 June 1936".

94. NASA, TAD, MJB, Volume 76, Reports of the Public Health Committee, 1936, "Jan Hofmeyr Township: Allocation of Houses under Housing Schemes", in "Report of the 
number was drawn from areas immediately adjoining the site of the Jan Hofmeyr scheme, namely Vrededorp (38\%), Fordsburg (16\%) and Brixton (14\%). The original dwellings of just $46 \%$ of these successful applicants were declared slums or in a bad or unsatisfactory condition, and staggering 69\% were state employees. Parnell reports that this latter percentage went down when the South African Railways and Harbours (SAR\&H) began providing housing for its employees. ${ }^{95}$ The overwhelming majority of successful applicants were Afrikaans-speakers. ${ }^{96}$ By July 1936, a further 76 applications were received. Of the total number of 930 applications, 930, only 165 (18\%) were successful. ${ }^{97}$

When the detailed task of devising the care model began, distinctions between the bureaucratic and political sections of the local state played out on the PHC. From the outset, Leveson propagated the rehabilitative qualities of housing schemes and a particular management model. Yet, these ideas were only finally adopted after city council bureaucrats had conducted independent research. When Councillor Leveson enquired about the criteria for tenant selection for the Jan Hofmeyr housing scheme, ${ }^{98}$ Dr Milne defended the autonomy of his department, stating that it was the sole responsibility of the director of housing. He proposed that final selection would be based on an assessment of the merits of each application and a close investigation of the applicant's present housing accommodation [my emphasis]. ${ }^{99}$ Dr Milne would not budge from this position, which for him was still the main aim of the housing scheme, because it enabled the application of the Slums Act. The MOH and the city engineer therefore reiterated their commitment to reserving space in the Jan Hofmeyr housing scheme for residents of areas that were dealt with under the Slums

Medical Officer of Health, prepared for the Public Health Committee meeting on 25 June 1936".

95. Parnell, "Council Housing Provision".

96. The surnames of at least $94(81 \%)$ of the 116 approved tenants are recognisably Afrikaans. Many of the other surnames could also plausibly belong to Afrikaansspeaking families and it is likely that more than $90 \%$ of the tenants were Afrikaansspeaking. This assumption is borne out by a note from the director of housing stating that most tenants "use the Afrikaans medium of speech". See TAD, MJB, Volume 76, Reports of the Public Health Committee, 1936, "Jan Hofmeyr Township: Progress Report by the Director of Housing", in "Report of the Medical Officer of Health, prepared for the Public Health Committee meeting, 27 August 1936".

97. Parnell, "Public Housing as a Device", p 588.

98. NASA, TAD, MJB, Volume 72, Reports of the Public Health Committee, 1935, “Appointment of Lady Manageress (Housing Scheme) and Selection of Tenants", in "Report of the Medical Officer of Health, prepared for the Public Health Committee meeting on 6 June 1935".

99. NASA, TAD, MJB, Volume 72, Reports of the Public Health Committee, 1935, "Appointment of Lady Manageress (Housing Scheme) and Selection of Tenants", in "Report of the Medical Officer of Health, prepared for the Public Health Committee meeting on 6 June 1935". See also, Volume 72, Reports of the Public Health Committee, 1935, "Director of Housing", in "Report of the Medical Officer of Health, prepared for the Public Health Committee meeting on 6 June 1935. 
Act when they made a recommendation to decline an offer by the SARH to accommodate some of their employees in the Jan Hofmeyr scheme. This decision was made despite the fact that the offer seemed attractive in terms of guaranteed occupation and rent collection. ${ }^{100}$

Here we can see a shift beginning to take place in the way local authority officials, or bureaucrats in the Health Department in particular, understood the services they provided. An increased emphasis on the social welfare function of governance was expressed in a report of the Committee of Enquiry into Charitable and Social Work, about which a circular was sent to the PHC:

Municipalities should increasingly interest themselves in the work of charitable and social welfare agencies, and their Health Departments should more and more become the centre from which to build up and to organise the social welfare efforts of their specific areas. ${ }^{101}$

The responsibilities of the Public Health Department were expanding as well as changing, signifying a different kind of governmentality in Foucauldian terms, and bringing a rehabilitation vision to the core of governance. ${ }^{102}$ It was no longer political influence and pressure that called upon the bureaucratic state. Instead, what had initially been civil society and political influence was now being absorbed as a part of the civic social imaginary. Dr Milne's staff had been growing, both at the central level and at the scheme itself. Two years later, the Department of Social Work was established at the University of the Witwatersrand.

\section{Taking occupation: An inauspicious affair}

The first tenants took occupation on 12 June 1936, although budgetary constraints meant that neither the lighting project nor the roads were completed.103 An ongoing dispute between the Parks and Estates Department and the PHC about which of the two departments had to bear the costs attached to laying out the parks caused a delay

100. NASA, TAD, MJB, Joint Report by Medical Officer of Health and Acting City Engineer to Public Health Committee, November 14th 1935.

101. NASA, TAD, MJB, Volume 71, Reports of the Public Works Committee, 1935, "Charitable and Social Work", in "Report of the Medical Officer of Health, prepared for Public Health Committee meeting on 28 February1935.

102. For a review of how this regime of care was implemented, in Epping Garden Village (formerly Ruyterwacht) in Cape Town over seven decades and the remaining traces thereof in post-apartheid Jan Hofmeyr, see Teppo, The Making of a Good White; A. Teppo, "A Decent Place? Space and Morality in a Former 'Poor White' Suburb", in M. Steyn and M. van Zyl, The Prize and the Price: Shaping Sexualities in South Africa (HSRC Press, Cape Town, 2009); and Du Plessis, "Living in Jan Bom".

103. NASA, TAD, MJB, Volume 76, Reports of the Public Health Committee, 1936, "Jan Hofmeyr Township: Progress Report by the Director of Housing", in "Report of the Medical Officer of Health, prepared for the Public Health Committee meeting, 27 August 1936". 
on that particular front. ${ }^{104}$ The vigilant middle class Residents' Association were quick to pick up on this oversight. ${ }^{105}$

Occupation took place in drips and drabs. The housing contractor completed the scheme in sections, and as a group of cottages became available, tenants were placed. But approving tenants was time-consuming and ensuring that approved tenants' move-in dates coincided with the demolition of their slum property was a challenging task.

On Friday, 17 July 1936, a visit to Jan Hofmeyr township was arranged for members of the PHC, the acting $\mathrm{MOH}$, Dr Laing, and press representatives. But the conditions of the roads (or rather the lack thereof) and an unsightly rubbish tip marred the impression the new housing scheme made on the group of visitors. ${ }^{106}$

By the end of 1936, most of the 165 tenants had been placed and only a few units were still vacant. The project of rehabilitating tenants on Octavia Hill principles and its local adaptation, now began to take shape. In August 1936, a competition was launched as the first such initiative. Prizes were to be awarded to tenants with the best flower gardens by the end of June 1937.107 It was reported that when her work load permitted, the housing manageress visited tenants in their homes. The report noted that she was "well received" by the residents. ${ }^{108}$

104. NASA, TAD, MJB, Volume 76, Reports of the Public Health Committee, 1936, "Jan Hofmeyr Township: Progress Report", in "Report of the Medical Officer of Health, prepared for the Public Health Committee meeting on 30 July 1936. What could have been foreseen, but was not picked up in the planning process, is that a landfill project was required to level the large park that was meant to be used for recreation and sports purposes. Even if the Parks \& Estates Department were to take responsibility for the cost of establishing the parks in the Jan Hofmeyr scheme, someone else had to cover the much larger cost of the landfill work.

105. NASA, TAD, MJB, Volume 74, Reports of the Public Health Committee, 1936, "SubEconomic Housing Scheme, Jan Hofmeyr" in "City Engineer's Department Report, prepared for the Public Health Committee meeting on 30 January 1936. Note also that In January 1936, the Richmond, Sunnyside, Cottesloe and Braamfontein Werf Ratepayers and Tenants Association, who had opposed the development of the Hofmeyr scheme all along, wrote a letter of complaint stating that “... the present condition of the ground will not lend itself to gardens, therefore something will have to be done to enable the public to visualise the beautiful picture that was painted by a few of the Slum Housing Councillors at the time the scheme was proposed and was opposed by this and all Associations in the adjoining districts".

106. NASA, TAD, MJB, Reports of the Public Health Committee, 1936, "Jan Hofmeyr Township: Progress Report", in "Report of the Medical Officer of Health", 30 July 1936, prepared for the Public Health Committee meeting.

107. NASA, TAD, MJB, Volume 76, Reports of the Public Health Committee, 1936, "Jan Hofmeyr Township: Progress Report by the Director of Housing", prepared for the Public Health Committee Meeting.

108. NASA, TAD MJB, Volume 76, “Jan Hofmeyr Township: Progress Report by the Director of Housing", in "Report of the Medical Officer of Health", 27 August 1936, prepared for 


\section{Conclusion}

As key role-players, Dr Milne and Councillor Leveson brought differences in emphasis and approach to the conceptualisation of the Jan Hofmeyr housing scheme. This derived, in part, from the differing roles they occupied in the local state formation, those of a bureaucrat and an elected politician respectively. More importantly, perhaps, the civic social imaginaries that shaped their understanding of their work drew on different sources.

Dr A.L. Milne saw himself as a professional instituting a scientifically-informed and methodical practice in the way he dealt with matters of city health. His was a distinctly global civic social imaginary shaped by imperial motives. In his own words, he had tackled various challenges with great success in countries all over the world. He had dealt with malaria, smallpox and plague epidemics in Mauritius; played a pivotal role in containing the influenza epidemic of 1918 in Johannesburg; and fought malaria and plague epidemics in Ceylon. ${ }^{109}$ Furthermore, he had received recognition for his efforts from London, the metropolitan "headquarters of hygiene and sanitation". ${ }^{110}$ He prided himself on having established a three-mile rodent-free belt around Johannesburg and thought that the Public Health Department, under his leadership, could compare favourably with any great city in South Africa or elsewhere. ${ }^{111} \mathrm{He}$ was therefore a colonial-era city bureaucrat with a set of organising frameworks and a modernist sensibility that emphasised macro-level planning, spatial order, scientific method and legality. He appears to have been frustrated about his inability to bring the slums in Johannesburg under control.

However, while embracing the possibilities of the Slums Act, he largely resisted intervention by politicians and civil society organisations and claimed autonomy for his department based on expertise, planning and the law. In the case of Jan Hofmeyr, he remained consistent in his view that the purpose of the scheme was to provide alternative accommodation for those whites whose current accommodation was highly unsatisfactory in areas declared to be slums. Broadly supportive of the idea to use the white housing scheme as a means of rehabilitation, housing schemes remained for him primarily a way to meet the alternative housing condition specifications of the Slums Act and therefore a way to advance slum clearance. Yet, he continued to push up the standard specifications for alternative

the Public Health Committee Meeting.

109. NASA, TAD, MJB, Volume 71, Reports of the Public Health Committee, 1935, "Salary Increases: Medical Officer of Health", prepared for a Public Health Committee Meeting on 31 January 1935.

110. "Old Methods Not Good Enough. Modern Needs for Health", The Star, 12 February 1936.

111. "Old Methods Not Good Enough. Modern Needs for Health", The Star, 12 February 1936. Incidentally, he also felt that he should be remunerated at least at the same level as the City Engineer. In his opinion these were the two most central positions in the Johannesburg City Council bureaucracy. 
accommodation stipulated in the Slums Act, keeping his eye on the latest changes from London, even though he understood the cost implications. The evidence suggests that Dr Milne saw the need to separate what he called "the races" in the city; that he subscribed to a belief about the superiority of whites; and was prepared to use the instruments he had available to enact racial segregation and racial social differentiation. But at the same time, the $\mathrm{MOH}$ had a conservative interpretation of the pieces of legislation at his disposal and was not prepared to bend these in the interests of more expressly political concerns. His imaginary of the relation between the city's residents had an abstract and impersonal quality, expressed through the image of the plan, the scale model, the map; and the by-law.

Lionel Leveson was a charismatic figure, readily engaging with a wide range of social actors. A city councillor, member and later chairman of the PHC, and director of the JHUC, he was central to the genesis of the white housing project. He conceptualised the project of housing provision as a race project directly connected to the idea of social upliftment and rehabilitation of poor whites. His aim was to turn them into worthy, productive, beneficial citizens. Whiteness, was therefore central to the kind of civic social imaginary that shaped his vision for Johannesburg; he imagined it as a firm, paternalistic relationship, a class pact. Although the Octavia Hill management model was his ideal, his comments suggest that oversight and supervision were the key aspects of the model he cared for most. As an elected councillor he was vulnerable to white public opinion. Yet in order to translate his vision into practice, he needed to popularise this idea among the white middle-class and elites. Ironically, in order to do so, he cast the white poor both as potential menace (in relation to disease, the spread of vice, and political unrest) and potential allies in need of paternalistic support. His is therefore a different kind of imaginary unlike that of the volksmoeder (mother of the people) that was adopted by Afrikaner nationalists. As an elected politician, his interests were social, and ground-level. Precisely because of this he was more attuned to the particular characteristics of his constituency in Vrededorp, and it was largely through his efforts that the Jan Hofmeyr scheme was adapted somewhat culturally for its primary constituency, the poor white Afrikaners.

A third civic social imaginary, in embryonic form, can be identified. Once the Octavia Hill manageress was appointed, she became the interface between tenants and the state; she became the local state. In a subtly argued account of the Octavia Hill management model in South Africa, Robinson, emphasises the gendered nature of the Octavia Hill model with its focus on cultivating friendship in the domestic space. Using the Foucauldian language of governmentality and surveillance and Bourdieusian language of unequal power domination, she nonetheless does not rule out that friendship could be possible and affirming. The problems she identifies with the role expectations of managers are the double role of friendship and rent collection, an uneasy mix, and the cultural remoteness of managers from the tenant community. In some circumstances this may well have produced a broader and softer model of social upliftment than Leveson preferred, but falls outside the scope of this paper. 
On the success of the Jan Hofmeyr scheme and sub-economic council housing schemes more generally, Parnell's assessment is that by the end of the 1930s, council had been unsuccessful in clearing slums and removing the majority of whites, largely because of the limited number of sub-economic rental units. In terms of its aim to rehabilitate or "uplift" whites socially and morally, Parnell felt that the exact aims remained unclear. Yet, focusing only on tenants' income levels, (economic rehabilitation), the period between 1936 and 1938 showed a dramatic upward trend. Only about $10 \%$ of tenants (20 out of 194 ) were in arrears in payment of their rent. In this narrow sense, then, the scheme was successful, but the dice was loaded, so to speak. The selection process predicted a greater success by eliminating less suitable applicants. ${ }^{112}$ Moreover, at this point, applicants who were earning more were not yet being asked to leave the estate. Because of high costs as well as the difficulties associated with tenant selection, coupled with changed conditions after the Second World War, sub-economic housing for whites was quickly abandoned by Johannesburg's city council. ${ }^{113}$

More recently, some authors have also considered the poor white housing scheme rehabilitation projects of the 1930s. Teppo, in a study over seven decades of the Epping Garden Village, run by the Citizens Housing League in Cape Town in 1938, draws on Foucauldian language, making the case for an invasive, harsh social moulding regime premised on the transgression of boundaries. However, Epping Garden Village was not a council housing scheme and furthermore was not run on the Octavia Hill model. There is no account of the actual care regimes in Jan Hofmeyr. In 2004, almost seven decades after its establishment, Du Plessis noted a culture of dependency and ingratiation in relation to the local housing officer. The tenant management system was reported to have been abandoned twenty years before, by which time it had turned into an inspection model. The researcher found traces of the past system, picked up in the over-willingness of some of the elderly residents to invite her into the private spaces of the residence, ${ }^{114}$ possibly a residue of the idea that good housekeeping necessitates no boundaries. Soon thereafter, the Jan Hofmeyr scheme was titled and sold to occupants at prices far below their value.

The siting of the Jan Hofmeyr housing project meant that Johannesburg's first public housing scheme was established in the heart of what was symbolically the de facto concentration of white Afrikaner poverty in the city. It was also the site of a range of black residential areas that were destined to be cleared by forced removals

112. Parnell, "Public Housing as a Device”, pp 590-592.

113. Parnell, "Council Housing Provision”; Parnell, "Public Housing as a Device”, p 585. After the completion of this scheme, an additional 70 houses and 48 flats were built at the Maurice Freeman/Bertrams development in 1939 and 94 houses and 24 flats at the Pioneer/Glenesk scheme in the south before the idea of sub-economic housing provision was abandoned and the council policy shifted to the provision of council housing on an economic basis, i.e. where rentals covered the cost of the schemes. The South Hills/Klipriviersberg scheme in Johannesburg was established on this basis.

114. Du Plessis, "Living in Jan Bom”. 
over time. In the 1940s, apartment units were added to the Jan Hofmeyr housing development on Caroline Street. In addition, the council built the Vredepark development, a series of self-catering units for the white aged, comprising three apartment blocks with 18 units each. The city council also owned 120 additional units in Vrededorp and 33 of the Radio Cottage units in Cottesloe - both neighbourhoods directly bordering on Jan Hofmeyr.

In total, therefore, council housing provision in the Jan Hofmeyr area was 444 units, establishing a deep welfare node in this part of the city. This contributed to the consolidation of a white welfare node centred on the white Afrikaner poor. Over four decades of Afrikaner Nationalist rule, commencing in the late 1940s, two higher education institutions - a teacher training college, Goudstad Kollege and the Rand Afrikaans University - were later established to deepen the bid for inclusion in the white working classes. With the headquarters of both the public broadcaster and the Afrikaner Broederbond in nearby Auckland Park, the broader area increased in importance in the Afrikaner nationalist social imaginary. As the Afrikaner nationalist class compact came unstuck in the late 1980 s, ${ }^{115}$ a TV series based on the increasing class disparities between white Afrikaans-speakers, entitled "Agter Elke Man", was partly shot in Jan Hofmeyr. The wound of white poverty was thus kept open. Ironically, in the post-apartheid period, a film based on Marlene van Niekerk's novel Triumph about Afrikaner poor whites under apartheid, was also shot in Jan Hofmeyr, although its accurate historical location was in the suburb Triomf (Triumph) built further to the west on the ruins of Sophiatown, following renewed aims to whiten the city by means of the apartheid era's forced removals in 1955. This incorrect location of the film's setting is highly suggestive of Jan Hofmeyr's iconic status both as signifier of the city's modern white upliftment projects, premised on racial segregation, and the degradation of white Afrikaner poverty in Johannesburg.

\section{REFERENCES}

Beavon, K., Johannesburg: The Making and Shaping of the City (UNISA Press, Pretoria, 2004).

Du Plessis, I., "Living in Jan Bom: Making and Imagining Lives after Apartheid in a Council Housing Scheme in Johannesburg", Current Sociology, 52, 5 (2004).

Hyslop, J., "Why did Apartheid's Supporters Capitulate? 'Whiteness', Class and Consumption in South Africa, 1985-1995”, Society in Transition, 31, 1 (2000).

Klausen, S., "Poor Whiteism, White Maternal Mortality and the Promotion of Public Health in South Africa: The Department of Public Health's Endorsement of Contraceptive Services, 1930-1938", South African Historical Journal, 45, 1 (2001).

115. J. Hyslop, “Why did Apartheid's Supporters Capitulate? 'Whiteness', Class and Consumption in South Africa, 1985-1995”, Society in Transition, 31, 1 (2000). 
Klausen, S., “Women's Resistance to Eugenic Birth Control in Johannesburg, 1930-39, South African Historical Journal, 50, 1 (2004).

Parnell, S.M., "Council Housing Provision for Whites, 1920-1955”, MA dissertation, University of the Witwatersrand, 1987.

Parnell, S., "Public Housing as a Device for White Residential Segregation in Johannesburg, 1934-1953", Urban Geography, 9, 6 (1988).

Parnell, S., "Racial Segregation in Johannesburg", South African Geographical Journal, 70, 2 (1988).

Parnell, S., "Land Acquisition and the Changing Residential Face of Johannesburg, 1930-1955", Area, 20, 4 (December 1988).

Poggi, G., Weber: A Short Introduction (Cambridge, Polity Press, 2006).

Rich, P., "Race, Science and the Legitimation of White Supremacy in South Africa", 1902-1940, The International Journal of African Historical Studies, 23, 4 (1990).

Robinson, J., “Octavia Hill Women Housing Managers in South Africa: Femininity and Urban Government”, Journal of Historical Geography, 24, 4 (1998).

Smith, A.J., Johannesburg Street Names: A Dictionary of Street, Suburb and Other PlaceNames, Compiled to the End of 1968 (Juta, Cape Town, 1971).

Stals, E.L.P. (ed.), Afrikaners in die Goudstad, Deel 2 (HAUM, Pretoria, 1986).

Swanson, M.W., "The Sanitation Syndrome: Bubonic Plague and Urban Native Policy in the Cape Colony, 1900-1909", The Journal of African History, 18, 3 (1977).

Taylor, C., Modern Social Imaginaries (Duke University Press, Durham, 2005).

Teppo, A., The Making of a Good White: The Historical Ethnography of the Rehabilitation of Poor Whites in a Suburb of Cape Town (Helsinki University Press, Helsinki, 2004).

Teppo, A., "A Decent Place? Space and Morality in a Former 'Poor White' Suburb", in M. Steyn and M. van Zyl, The Prize and the Price: Shaping Sexualities in South Africa (HSRC Press, Cape Town, 2009) 